\title{
Right to Life Under the Yoke of Environmental Pollution in the Niger Delta of Nigeria
}

\author{
Aniekan Mendie \\ Department of Business Administration \& Management, Federal Polytechnic, Bauchi, Nigeria.
}

\author{
Doi:10.5901/jesr.2014.v4n7p9
}

\begin{abstract}
This Paper maintained a topical focus on right to life which is the most fundamental of all rights, without which no man can enjoyed other rights. With open insistence on the fact that right to life permeates every race, clime and culture, the paper accepted the universality of the right. In fact, in the context of this paper, right to life is considered against the background of the condition of huge environmental pollution, among other militating conditions, in the Niger Delta. The thematic thought underscored in the finding of this paper is that with overwhelming environmental pollutions engendered by oil and gas exploration and exploitation activities undertaken by Oil and Gas Multi-Million Naira Companies with their State Collaborators, among other negative conditions, right to life, the hub which other rights revolve is hardly realized by the people, especially, the poor rural dwellers in the Niger Delta. It is not in the contemplation of this paper that natural resources in the Niger Delta need not be exploited, but the paper in the spirit of human rights activism and environmentalism favoured resource exploitation capable of exploding massive environmental pollution, harmful to human life along the lines of environmentally friendly procedures, ensuring environmental sustainability and respect for right to life. The paper used provisions of law; judicial authorities; and materials from Journals, Law Texts, Newspapers and Internet to buttress the kernel of its arguments and made recommendations in the end.
\end{abstract}

Keywords: Right of Life: Environment; Environmental Pollution; Niger Delta.

\section{Introduction}

The people of Niger Delta, a place which is mainly by distinctive geographical characteristics, a coastal, erosion-ravaged and swampy community located largely at the South-South zone of Nigeria exist under the yoke of scandalous oil pollution and suffer excruciating pains of oil and gas related diseases with little or no access to efficient medical facilities. This condition makes life unbearable to the people. It is in view of the forgoing that this paper as broken into sub heads explains the concepts of environment and environmental pollution in relation to right to life in the Niger Delta. In the end, the paper made some recommendations to help the protection, enforcement and enjoyment of the right, among other rights.

\section{Right to Life}

This is one of the rights in the bundle of fundamental rights guaranteed under Chapter iv of the Nigerian Constitution, 1999 as amended. The right is the fulcrum of all other human rights inherent in the nature of man. Lamentably, there is no clean environment for enjoyment of the right in Nigeria; and in the Niger Delta in particular. The point that needs to be made is that enactment of right to clean and healthful environment as fundamental and justifiable right should be effected through urgent legislative action since the right appears inseparable with right to life. Indeed, a dignified human life must be lived in a clean, unpolluted and conducive environment. In that context, right to life means right to clean, unpolluted and healthful environment. Thus, both rights suppose to be enforced together before the Courts in appropriate circumstances. In fact, it has been observed that:-

Modern human rights encompasses virtually all fields of human endeavour, and has extended from the traditional civil and political liberties to economic, social and cultural rights, the third and fourth generation rights relating to peace, the environment and rights of the vulnerable stratum of the society e.t.c. (Civil Liberties Organization, 1996)

The observation above is in line with the persuasive and exemplary decision of the Indian Supreme Court in Mohini Jain v. State of Karnataka (1992) where the Court held that: "right to life is the compendious expression for all those rights which the Court must enforce because they are basic to the dignified enjoyment of life. Eze (1984) joining the train of thought above asserted in his usual demonstration of eloquence that: "The right to environment is directly related to right to life and health without which there can be no development". Regrettably, right to clean environment is 
not guaranteed in the Nigerian Constitution, 1999 as amended. Thus, the fate of right to life in Niger Delta in the midst of hugely polluted environment is precarious.

\section{Concept of Environment and Environmental Pollution}

In our Constitution, the grund norm, the term, "environment" is defined to include water, air and land, forest and wild life of Nigeria.(S.20 of Nigerian Constitution, 1999). In another statutory but inclusive definition under S.37 of the National Environmental Standards and Regulatory Agency Act, 2004 (NESREAA) made pursuant to the grund norm afore-cited, the term, "environment" is defined to embrace: water, air, land and all plants and human beings or animals living therein and the interrelationships which exist among these or any of them." Lexically, environment also has been defined to mean: "the totality of physical, economic, cultural, aestheic and social circumstances and factors which surround and affect the quality of people lives." (Black, 1990:534). There may be various definitions of environment by different writers but the broader definition of the term under the NESREAA, 2004 has caught our fancy here. Right or left, environment involves the interaction of the atmosphere, hydrosphere, lithosphere and biosphere components as conditioned either by nature or affected by man, the exploiter of the environment.

What constitutes environmental pollution is shown under the NESREAA to mean: "Man-made or man aided alteration of chemical, physical or biological quality of the environment beyond acceptable limits. What constitutes acceptable limit of pollution is not made comprehensible to the poor victims of oil pollution in the Niger Delta by the Nigerian Law; even though S.37 of NESREAA, 2004 has defined:

"effluent limitation" as any restriction established by the Agency of quantities, rates and concentration of chemical, physical, biological or other constituents which are discharged from point sources into waters in Nigeria. "

In the definition above, quantities, rates and concentration of pollutants acceptable are mentioned only in relation to waters; (How about air and land?) and they are not given mathematical expression to the understanding of the common man. Besides, the standard of acceptable pollution is to be determined by the Environmental Agency, a Government Agency subjectively and not by the court from circumstance and manifest evidence in the pollution case. (S. 37 of NESREA, 2004). It is our submission that oil related pollutants even in their minute forms are potentially harmful and hazardous either in the short or long run to human and animal health as well as the natural environment. Human acceptance and endurance are not therefore, solutions to environmental pollution at any level of its effect. Consistent actions are required to tackle pollution in order to rescue humanity and the environment.

Furthermore, Siegel (1974:277) looks at environmental pollution as: "the alteration of natural environments, air, water, soil which renders them offensive or deleterious to aesthetic senses, or for man uses, or for the animal, fish, or crops which man wishes to preserve." From Siegel's view above, environmental pollution can be broken into atmospheric, water and soil pollution. Pollution of the environment also has been seen as "the introduction of contaminants into the natural environment that causes adverse change."(http://en.wikipedia.org/wiki/Envi...). Environmental Pollution can emanate from various sources which include hazardous substances, organic waste, toxic chemicals, noise, and heat etcetera. Pollution occasions disequilibrium of eco- systemic balance; and disruption between living species and their natural environment.

A second look at S. 37 of NESREAA, 2004 reveals that environmental pollution can be directly caused by man or by nature but aided by man for a prolonged or continuous adverse effects. Hence, one can rightly submit that environmental pollution can occur in the nature of any condition resulting either naturally, as in torrential rainfall or artificially as in human exploitation of natural resources, effect of which adversely alter, corrupt or despoil the environment. In a way that the environmental sustainability for human, animal, aquatic and plant lives including physical property is drastically reduced or completely extinct. What is left to be added is that in a condition where huge environmental pollution persistently occur and remain unabated as in the Niger Delta, right to life, of all basic rights, is generally the worse hit.

\section{Major Sources of Environmental Pollution in Niger Delta}

The key term under this sub-unit is the word, "sources". The word, sources is a significant terminology which is used in our context to connote the various causes or points of origin or materials from which environmental pollution in the Niger Delta emanates. It is to be noted that the category of sources of environmental pollution is not closed; as new ones keep emerging. Thus, the concept of "new source" has been defined by S. 37 of the NESREAA, 2004 cited above to mean "any source, the construction of which is commenced after the publication of any regulations prescribing a standard to 
such source". Besides, Section 37 of NESREAA, 2004 makes mention of the terms, "point source" and defines same as "any discernible, confined and discrete conveyance, including but not limited to any pipe, ditch, channel, tunnel, conduit, well, discrete fissures, container, rolling stock, concentrated animal feeding operation or vessel, or other floating craft from which pollutants are or may be discharged".

For a comprehensible presentation, one shall proceed in the discussion here under three headings nam1y, sources of water, air and soil pollution.

\section{Sources of Water Pollution}

Water in the Niger Delta refers to different bodies of water such as rivers, creeks, streams, lakes, oceans and seas, rainfalls, lagoons and water beneath the surface of the soil, that is underground water; such as wells springs etcetera. (Okorodudu-Fubara, 1998: 585). There is no gain saying that water supports human, animal and plant lives. Unfortunately, the large body of water in the Niger Delta is not fit for human consumption as its quality is contaminated by oil spillages. The chief sources of water pollution in the Niger Delta include: crude oil, industrial waste, agricultural waste, refuse and sewage.

Crude Oil: The common truth is that many multi-national oil companies carry out their industrial and commercial activities in the Niger Delta. Specifically, Shell Petroleum Development Company of Nigeria, Mobil, Agip, Elf and Chevron Oil Companies etcetera, operate at various areas of the Delta. Nigerian National Petroleum Corporation, Oil Refineries and Petrol Chemical Plants also do business in the Delta Region. These companies explore and exploit crude oil for profits in the Delta. This crude oil pollutes seas, coastal waters and land in the Niger Delta through spillages from oiltankers, oil pipelines, off shore oil wells and sea going vessels and oil ships. Oil spillages in water are normally "toxic, affecting lungs, livers and kidneys in animals. (Ramalingam, 1990: 154). Oil covered animals usually suffocate (Ramalingam, 1998). Large oil spills generally devastate ecosystem in the Niger Delta, poison sea food, fish, water birds and animals. Fishermen in the Niger Delta are usually negatively affected as their sources of livelihood are destroyed. Stream sources which provide drinkable water for rural people in the region remain heavily contaminated beyond use by oil spills and this affects right to life adversely. It needs not be over-emphasized that oil spills remain a common phenomenon massively polluting farmland and water sources in the Niger Delta. In fact, a report has it that between 1976 and 2001, 6,817 oil spills occurred with a loss of approximately three million barrels of oil. (Babatunde citing UNDP Report, 2006). All that oil spilled into the environment causing adverse consequences. Yet, more is still spilling.

Industrial Waste: Factories, mining and smelting works, refineries and power plants are main sources that pollute water with industrial chemical waste. (Ramalingam, 1990). There are oil refineries located at Port-Harcourt in Rivers State; Warri in Delta State and Petro-chemical Plant at Eleme also in River State. National Fertilizer Company of Nigeria (NAFCON) at Rivers State and Delta Steel in Delta State are also there in the Niger Delta. These refineries and petrochemical plants generate acidic wastes which flow into water sources and pollute them. Industrial wastes in form of acids, alkalis, organic solvents, detergents, oils, dyes and heavy metals introduce harmful substances like mercury, copper and lead into water. Industrial effluent discharged into open drains, gutters also flow into creeks, streams and rivers. These reduce water quality and cause extensive damage to marine lives which suffocate and die for want of oxygen in the water medium. Industrial chemical wastes are usually non-biodegradable and so remain for a long time to poison the food chain; pollute the water and reduce its quality and contaminate sea food therein beyond human use.

Agricultural Wastes: In the Niger Delta, pesticides and fertilizers are used in farming. Pesticides are synthetic organic compounds that are non-biodegradable. (Ramalingam, 1990: 153) Some of these compounds can accumulate in the bodies of plants and animals (Ramalingam, 1990). Thus, affecting the food chain. Fertilizers are inorganic salts. (Ramalingam, 1990). The most common salt is nitrate which is capable of getting into the ground water and other water bodies and renders them undrinkable and unfit for human consumption. It has been noted that high concentration of nitrate in drinking water constitutes health risk especially in babies and young children (Ramalingam, 1990). Agricultural waste, therefore remain one the sources of environmental pollution in the Niger Delta.

Refuse and Sewage: Refuse is mainly household or domestic waste while sewage is the waste product excreted from the human bodies. Some people living in the Niger Delta which is mainly riverine in nature pass all sort of human excreta into water bodies in the area, thereby polluting them beyond use. Underground pipes carrying sewage are sometimes being emptied into the rivers through water closet (WC), lavatories in the area. This reduces oxygen level in the waters and causes suffocation to aquatic lives. Water borne diseases are then, partly caused by water polluted by refuse and sewage in the area.

Sources of Air Pollution: In the Niger Delta, atmospheric pollution affecting human right to life is caused, among 
others, by:

(a) Industrial effluents, the substances produced when fossil fuels like oil and natural gas are burnt.

(b) Chlorofluoro carbons

(c) Noise produced by vehicles, air crafts, heavy duty machineries and humans.

(d) Gas flaring etcetera.

Refineries, gas and petrochemical plants, fertilizer and steel companies, incinerators, motor vehicles, generators and home furnaces release various pollutants which include different gasses, smoke, soot, dust and grit into the air in Niger Delta. For instance, carbon monoxide is a poisonous gas formed whenever fuel is incompletely burnt. This gas is experienced in places of high vehicular movement like Port Harcourt, Warri, Calabar, Uyo, Benin City etcetera, in the Niger Delta. This gas normally competes with oxygen which is essential for cellular respiration in human beings. Concentration of carbon monoxide generally reduces air quality and causes dizziness, headache, nausea and tedium in people. Another gas is hydrocarbon which is released into the Niger Delta air when volatile fuels evaporate from storage tanks by the petrochemical plants. Hydrocarbon is believed to cause cancer in human. (Ramalingam, 1990). It has been noted that localized air pollution problems of particular concern are particulates e.g cement, klin dust, nitrogen compounds from the fertilizer plant (NAFCON) and multiple pollutants from Nigeria National Petroleum Corporation (NNPC), refineries in Warri and Port Harcourt in the Niger Delta. (Ajao and Anurigwo: www.greendiary.com/.../niger_delta-on-fire-demands-solution).

Furthermore, gas-flaring from oil production which is a wasteful emission of greenhouse gases that increases global warming is another source of air pollution in the Niger Delta. The noise and increased temperatures are local problems in the immediate surroundings of the flares in the Niger Delta. The flares are associated with acidification resulting in rapid deterioration of galvanized sheets used commonly in the Delta area. (Ajao and Anurigwo, 2013). Of course, roofing sheets in buildings are fast rusting in the area because of the flares. Gas flaring causes Ozone layer depletion and induces acid rain. In the Delta Region, wild life is adversely affected in the area of flares as animals are forced to flee their habitats, with some of them losing their lives in the process. Agricultural land is rendered useless by the flares and local farmers are driven out of their farming occupation. Pity! No land farming. No sea fishing. No means of livelihood. No right to life.

Sources of Soil Pollution: Soil pollution is the damage of the layer of the top soil that sustains the ecosystem and maintains a good landscape for human activities. The sources of land pollution in the Niger Delta include erosion, dumping of toxic domestic, industrial and agricultural wastes on land. In the Delta area, garbage is seen in heaps in compounds of buildings, on streets, road sides; farm land and by river banks and also in gutters. Thus, garbage dumps constitute health problems as they spread diseases to human beings. Besides, oil spillages, oil- well blow out setting the green ablaze also pollute land in the Delta region. Gas flaring also renders the Delta land not useful for farming. Those whose lives depend on farming are forced by flares to abandon their land. Hence, they lost their means of livelihood; and right to life without means of livelihood for Niger Delta dwellers means nothing. This trend offends the legal position as maintained in the consolidated Suit of Abdulrasaq \& 3 Others v. Inspector General of Police \& 5 Others (1991/94) that: right to life includes right to livelihood.

\section{Specific Occurrences of Oil Pollution as Impediment to the Realization of Right to Life in the Niger Delta}

Some occurrences of oil pollution hampering the realization of right to life in the Niger Delta are intended to be discussed under this unit. Oil pollution is caused by oil spills which have been defined as uncontrolled releases of any product relating to oil production including crude oil, chemicals, or waste caused by equipment failure, operation mishaps, human error or intentional damage to facilities. (Babatunde citing Constitutional Rights Project: http://www.review.upeace. org/index.cfm?opcion=0\&ejemplar=20...). This discussion shall further proceed on a State by State basis.

Bayelsa State: Oloibiri Community is today under Bayelsa State. It is in that Community that extraction of oil first started in Commercial quantities in 1958 in Nigeria. Osamwonyi Obasogie writes that what most people do not know today is that Oloibiri Community is no longer inhabited by the people. (Obasogie, 2008). It is submitted that where in a Community such as Oloibiri where the indigenous people are forced to vacate and migrate from their homes due to the devastating environmental impacts of oil extraction, right to life is seriously threatened. Unarguably, right to life includes the bare necessaries of life such as shelter which the people of Oloibiri are being made to vacate and migrate due to oil exploitation and its environmental pollution. This trend is creating a disconnect between right to life and shelter right, both rights which suppose to be enjoyed together in the real sense. It is a high time for the Nigerian Judiciary to begin to follow the persuasive decision in the Indian case of Francis Coralie v. Union Territory of New Delhi (1981) where it was held 
that: "right to life includes the right to live with human dignity and all that goes along with it, namely the bare necessaries of life such as adequate nutrition, clothing and shelter".

On 12th January, 1992 at Ikebiri Community in Bayelsa State extensive environmental pollution occurred through incessant oil spills from ageing pipeline. (Civil Liberties Organization, 2002:63) Gas fire ignited by the spills razed down Ikebiri Community forest completely. A report has it that Agip Oil responded by giving out money to a part of the Community and that provoked some leadership problem. (Civil Liberties Organization, 2002). Matters, however, got out of hand when Agip donated a Speed Boat to Ikebiri II Community. A struggle started about who maintained control of the Boat. Soldiers and Security Guards intervened, a mayhem followed and eight persons were killed and fifteen others were reported missing. (Civil Liberties Organization, 2002).

In another incidence, on $25^{\text {th }}$ October 1998 a major environmental pollution occurred in Shell's oil facilities at Santa Barbara Flow Station in Nembe Local Government Area, Bayelsa State. (Civil Liberties Organization, 2002). The Community of Gbaraun was left helpless and devastated due to the spills from a faulty high pressure pipeline that occurred from the Flow Station of Shell. The spills spread toxic crude oil into the creeks of Gbaraun Community and its environs for over two days. (Civil Liberties Organization, 2002). Aquatic lives were destroyed, and the spills affected about 50 fishing settlements as far as Rivers State. (Civil Liberties Organization, 2002).

In 1999 massive killing of the Odi people of Bayelsa State took place. The killing was carried out on orders of Nigerian Government which vowed to smoke out criminals suspected to have killed 12 Policemen in November, 1999. The Government acted to suppress Community protest against environmental pollution and economic inequity and in the process many lives of Odi Community Dwellers were lost. Odi case remains a worst case for human right to life in the Niger Delta. Justice Lambi Akanbi of the Federal High Court, Port Harcourt Division delivering judgment which awarded N37.6 billion only to Odi Community against the Federal Government of Nigeria held that:

The Respondents violated the fundamental human rights of the people of Odi by the Massacre. The people are entitled to fundamental right to life, dignity and fair play, the destruction of Odi was not as a result of gun battle but clear bombardment, the destruction was malicious.

(http://www.vanguard.ngr.com/2013/odi-invasion-court-orders-fg-t...)

This compensation of N37.6 billion as awarded by the learned Judge against the Government of Nigeria and in favour of Odi Community is yet to be paid, even when the Court ordered that payment be made within three weeks. Non compliance to Court order regarding payment of compensation cited above is worsening environmental pollution in the Niger Delta.

Rivers State: Ogoniland in Rivers State is another significant area of the Niger Delta that is witnessing repeated environmental degradation, ecological violence and infrastructural decay due to oil drilling activities by oil giant such as Shell and other companies tapping oil in commercial quantities in the area. The large scale pollution of Ogoniiand by oil companies caused late Ken Saro Wiwa to come up with the Ogoni Bill of Rights under the auspices of the Organization: Movement for the Survival of the Ogoni People (MOSOP). Ken Saro Wiwa, an environmentalist had the idea of actualizing right to self determination and resource control as method against environmental pollution, neglect and under development of Ogoni area. In his non-violent struggle against environmental pollution and environmental injustice, he paid the supreme price a1ong with eight others who were executed with him by the Federal Military Government of Nigeria in November, 1995. In August, 2006 well-head 13 which has not been operational since 1993 was sabotaged, and wild fire engulfed Ogoniland, leaving unfathomable devastation to the ecosystem, and perhaps latent damage to human health. (Obasogie, 2008). Some major spills involving urea in 1992 reportedly killed large numbers of fish in receiving waters (Okrika creeks) (Ajao and Anurigwo, 2013). That rendered fish farmers facing polluted waters with empty fishing nets without fish for a living. United Nations Environment Progamme (UNEP) assessment on Ogoniland has confirmed that oil pollution has damaged Ogoni Community in a terrible way. (UNEP Report: 2003, www.unep.org/...Nigeria/enviromental assessment of Ogoniland report). There is no gain saying that Niger Delta environment and its human dwellers are in dire need of environmental remediation, construction and pecuniary compensation.

Egiland is a Clan of 16 large Communities in Ogba-Egbema/Ndoni Local Government Area in Rivers State. Elf Petroleum Nigeria Limited started exploration for crude oil in Egiland in 1962. (Ajao and Anurigwo, 2013). The oil company appears to have disregarded the disastrous environmental impacts of oil exploration and exploitation in its policies. Thus, Egiland is carved out as an:

Ecological disaster with oil pollution devastating the soil, aquatic life and economic trees, spewing more than 2 million cubic metres of poisonous hydrocarbon gas into the atmosphere daily and causing pollution of water, food, fishing ponds, swamps and farmland. (Ajao and Anurigwo, 2013) 
In Egi, the major source of environmental pollution is the Obite Gas Plant, one of the facilities located in the Community to service the Bonny Liquefied Natural Gas Project. (Ajao and Anurigwo, 2013)

Delta State: Recently, oil spills from a ruptured pipeline belonging to a subsidiary of Nigeria, National Petroleum Corporation (NNPC) caused a fire out-break. Though no life was lost, the inferno ravaged up to ten Communities as it flowed through the river from Ohorhe II up to Ekpan in Uvwie area of Delta state. Streams and rivers especially in Ohorhe II were reported to have turned completely black as the gushing crude oil submerged water while farmlands and economic trees withered. (Egbulem, 2009:9). In another report of environmental pollution, oil spills occasioned by Shell Petroleum Development Company (SPDC) on 25 July, 2005 ravaged three agrarian communities of Iwhreka, Otujeremi and Edjophe, spreading also to Aboghia and Umolu Communities, all of Ughelli South Council of Delta State. (Ihemagbulem, 2005). The spills were said to have taken tolls on all farmlands and rivers, destroying crops and fish that are sources of the Communities' livelihood. (Egbulem, 2009:9). Again, SPDC was accused by Ugbokodo Community of Okpe Local Government Area in Delta State of oil spillages leading to sneezing, drowsiness and running of the nose and eyes in people who were directly inhaling the carbon and chemical of the crude oil spilled. (Anaize, 2005:8).

In 1998 crude oil related fire out break overwhelmed Jesse Town in Delta State. The disaster left 1,500 persons burnt to death and the subsistent Community was pushed into poverty as all economic activities paralyzed. (Anaize, 2005:8). That said, the popular Koko toxic waste dump that caused series of environmental havoc in Delta State is still fresh in human memory. This waste dump exposed the emptiness of environmental protection law in Nigeria and caused the enactment of the Federal Environmental Protection Agency Act, 1990, (FEPA) now repealed and replaced by National Environmental Standards and Regulations Agency Act, 2004. (NESRAA). The Act aims at the protection and maintenance of environmental quality in Nigeria, including Niger Delta.

Edo State: In June, 2000 pipeline ruptured near Egborode village in Okpe Local Government Area, Edo State, throwing petroleum into Omugba River. (Civil Liberty Organization, 1998: 109).One month later, a huge explosion causing fire burnt 300 people to death. (Civil Liberty Organization, 1998: 109). As in Jesse Town (Delta State), agricultural and economic life of the people was paralyzed.

Akwa Ibom State:Environmental pollution also occurred at Idoho Platform when a 12 inch pipeline linked to the Qua Iboe Terminal owned by Mobil Producing Nigeria Unlimited ruptured. The quantity of oil spilled was estimated by Mobil to be 40,000 barrels. (Civil Liberty Organization, 2002: 83). That spills caused ecological and environmental disaster in Akwa Ibom State. At least 25 persons were reported arrested and detained by the Police Command Headquarters, Akwa Ibom State due to protest against that environmental disaster. (Civil Liberty Organization, 2002).Mobil responded through its External Affairs Manager, Yomi Adeyemi and claimed that $90 \%$ of the oil spill had evaporated or disappeared naturally.(Civil Liberty Organization, 2002: 84). That the situation in the areas closest to the source of the spill was back to normal and that it appeared clear with only isolated areas of slight sheen. (Civil Liberty Organization, 2002: 84). Instead of commencing an action of environmental restoration, Mobil offered useless excuses that did not help the devastated environment to the extent of ensuring the realization of right to life.

\section{Environmental Pollution Related Diseases Affecting Right to Life in the Niger Delta}

Earlier in the previous units, we highlighted and discussed some sources and specific occurrences of environmental pollution affecting ecosystem and rubbishing fundamental right to life in the Niger Delta. Now, our concern is to show some diseases affecting human beings as a result of wide spread environmental pollution in the area. The term, "disease" in human beings is often used more broadly to refer to: "Any condition that causes extreme pain, dysfunction, distress, social problems, and/or death to the person afflicted, or similar problems for those in contact with the person. (Wikipedia, The Free Encyclopedia). Disease may, 'therefore, be simply defined as any abnormal condition that impairs normal bodily function and may result in human death. It is our contention that daily environmental pollution has become the source of series of diseases afflicting the people of the Niger Delta. Timi Alaibe, the former Managing Director of the Niger Delta Development Commission (NDDC) has accordingly expressed concern that: the level of air and ground water pollution... could be the cause of some strange health conditions now prevalent in the region. (Alaibe, http://allafrica.com/stories/2008102306 $96 \mathrm{html}$ ). He further maintained that: "ailments that have developed from drinkable water as well as inhalation of poisonous gasses are worse than HIVIAIDS.(Alaibe, http:// allafrica.com/stories/2008102306 $96 \mathrm{html}$ ). Flared gases caused higher temperatures and that much has been attested to by those residing in the areas where gas is flared. (Obasogie, 2008). One agrees with Obasogie (2008) that what is not determined, however, is the number of people who have developed Lung-related diseases, eye-defects or dermatological disease through exposure to gases, or developed cerebral meningitis from the rise in temperature. 
A recent study reveals that coastal areas of Niger Delta constitute a zone of disproportionately high mortality proneness to diseases such as: Measles, Malaria, Pneumonia, Tetanus, Dysentery and Tuberculosis. (Earth Rights Institute, http://www.earthrights.net/nigeria/news/defination, html). It has also been disclosed that water polluted with refuse and sewage can spread typhoid fever, cholera, dysentery and other diseases. (http://www.hedon unto/methanol stoves for indoor air pollution in Delta State Nigeria).

Carbon monoxides and other industrial carbon emissions released into the air by oil companies and Petrochemical Plants in the Delta region even in low concentration cause dizziness, headache, nausea and tedium in people. Science proves that these gaseous substances, if inhaled for a long time, even at low concentrations can cause brain damage in humans. (Ramalingam,1990:149). Higher concentrations can lead to unconsciousness and eventual death.(Ramalingam, 1990: 149). A source(Earth Rights Institute, http://www.earthrights.net/nigeria/news/defination, html)has stated that the consequences of oil and gas exploration from air, water and environmental pollution in the Niger Delta may affect the fertility and life span of the inhabitants in such a manner that fecundity may fall and the birth of abnormal babies and plants may increase. As a matter of fact, oil boom has brought oil doom as indicated in the prevalence of environmental pollution related diseases in the Niger Delta region. There is need now, as Timi Alaibe said, to embark on further research to ascertain if there is indeed any correlation between strange diseases and oil activities.(Alaibe, http://allafrica.com/stories/2008102306 $96 \mathrm{html}$ ). Indeed, a research result maintains that Nigerian crude oil could be hemotoxic and hepatotoxic, and could cause infertility and cancer. (Ordinioha and Brisibe, http://www.ncbi.nlm.nih.gov/ pmc/articles/pmc36447381)

\section{Selected Judicial Decisions in Environmental Pollution Cases as Samples of Judicial Attitude toward Enforcement of Right to Life in the Niger Delta}

At the formative stage of Nigeria as a Country, the Courts in their interpretation and application of laws tended to embrace legal positivism. In the words of Sylvester Shikyl (1997)"Courts exhibit a strong desire to serve the interest of the state security by adopting the literal and passive approach to interpretation of constitutional human rights provisions". This attitude of positive construction of laws changed with the authority of Rabiu v. State (1981) in which Udo Udoma, J.S.C gave a directive on the modern judicial approach and attitude to be adopted in interpretation of the provisions of the Constitution. His Lordship eloquently stated:

my Lords, it is my view that the approach of this court to the construction of the constitution should be, and so it has been, one of liberalism ...I do not conceive it to be the duty of this court so to construct any provisions of the constitution as to defeat, the obvious ends the constitution was designed to serve...

In further enunciation of the principle of judicial liberalism propounded by Udo Udoma, J.S.C; in Rabiu's case above, Lord Diplock reaffirmed in A.G. of the Gambia v. Jobe (1984) that:

A constitution and in particular that part of it which protects and entrenches fundamental rights and freedoms... is to be given a generous and purposive construction.

This judicial attitude has shifted from undue observation of rigidity and strict adherence to legal technicalities. This new judicial attitude towards enforcement of basic rights is sustained and enhanced by the Fundamental Rights (Enforcement Procedure) Rules, 2009 which in paragraph 3 (a) of its preamble declare that the overriding objective for courts to promote is that of advancing but never for the purpose of restricting the applicant's rights. It is therefore, the duty of Courts as observed by Justice Hugo Black in Chambers v. Florida (1940) to:

stand... as havens of refuge for those who might otherwise suffer because they are helpless, weak, out-numbered or are victims of prejudice or public excitement.

Courts now are enjoined to proactively pursue enhanced access to justice for all classes of litigates especially the poor, illiterate, uninformed, vulnerable, incarcerated and unrepresented Rabiu v. State (1981). To this end, a clear testimony of a highly commendable attitude of the Nigerian Judiciary towards enforcement of right to life was first significantly demonstrated by the Supreme Court in the locus classicus case of Aliu Bello v. A.G. of Oyo State (1996). In that case, the dependants of the deceased, an armed robbery convict filed an application challenging the unlawful execution of their bread-winner, whose appeal was formally pending before the Court of Appeal. The apex court frowned within the circumstances of the unlawful execution of the deceased in the following pronouncement:

This is the first case in this country... in which a legitimate Government of this country,' past and present; colonial or indigenous hastily and illegally snuffled off the life of an appellant whose appeal had vested and was in being, with no order of court upon appeal, and with reckless disregard for the life and liberty of the subject and the principle of rule of law. The brutal incidence has bespattered the face of Oyo State Government with the paint-brush of shame. 
With the above discussion, we have shown the general modern attitude of Court toward enforcement of basic right to life. Specifically, in this segment of the paper, it is our concern to show the attitude of Courts toward enforcement of right to life in environmental pollution matters in the Niger Delta. Of course, it is a well settled progressive view that "right to life is directly related to right to a healthful environment without which there can be no development (Akpamgbo 1992:28). The position therefore is that right to life in environmental pollution cases may be enforced under the procedure of the general writ of summons and not necessarily by application under the Fundamental Rights Enforcement Procedure Rules, 2009. In Nigeria generally, the basis of cause of action for enforcement of right to life may arise when an injury or damage which includes diseases, any impairment or physical or mental condition or death of any person is caused by a person, biological or corporate to another by any harmful waste or hazardous substance dumped on land or in water or released into the air. (S.12 (1) (2) of the Harmful Waste (Special Criminal Provisions) Act, 2004). Thus, in Seismograph Service (Nig.) Ltd v. Ogbeni (1976) the Court held that the plaintiff has a cause of action which entitled him to sue for nuisance caused by the defendants and their agents in course of carrying out oil exploratory exercise of exploding the oil testing chemicals around the plaintiff's building, which wrongfully caused unbearable noise affecting his life and vibration which damaged the building.

In Shell Petroleum Development Company of Nig. Ltd v. Chief Otoko and others (1990) the Respondent complained bitterly of spillage of crude oil injuriously affecting fishermen, farmers, persons bathing and washing in the Andoni River and adjoining creeks and persons using the River for cassava processing. The High Court of Rivers State sitting at Bori awarded N491,700.00 as damages and cost of N1,500.00 to the Respondents. The Appellant appealed against that judgment. Omosun, J.C.A allowing the appeal held that: "...there was no joint tort, for damages caused to each of them (the respondents) can only be personal to each of them". This case illustrates the issue of joint action where the Court on appeal held that there was no joint locus standi and so the matter should fail. Perhaps, the decision of the appellate Court would have been different, where separate and personal actions were to be maintained. In another environmental pollution action in Mobil Producing Nigeria Unlimited v. Monokpo (2001) Ekpe J.C.A, held that:

If a number of persons jointly participate in the commission of a tort, each is responsible, jointly with each other and all of the others, and also severally for the whole amount of the damage caused by the tort, irrespective of the extent of his participation.

In the Indian example as shown in the case of Indian Council for Enviro-Legal Action v. Union of India (1996), the Respondent run chemical factories without licenses and equipment for treatment of highly toxic effluent. The Respondent's discharges polluted water into the soil. This led to action on-behalf of the villagers whose right to life was infringed by the Respondent's factories' activities. The Supreme Court of India held that:

Once the activity carried on is hazardous or inherently dangerous the person carry on such activity is liable to make good the loss caused to any other person by his activity.

In conclusive submission under this heading, one maintain that the judicial attitude in Adediran and Another v. Inter-land Transport Limited (1992) be adopted, where the Supreme Court held in an environmental action affecting both public and individual right that:

...both the individual affected by such nuisance and the Attorney General are at liberty to sue. In other words, they have equal right to do so. The former, as a private person and the later on behalf of the public at large.

\section{Conclusion}

When the position enunciated in the decision above is maintained as the functional judicial attitude, breaches of fundamental rights of person in the Niger Delta will no longer be denied in oil pollution related cases on the altar of the strict interpretation of locus standi. Persons affected in terms of their basic rights will have standing to sue, especially where the state remains passive and unwilling to act in evidently glaring circumstances of oil pollution cases in the Niger Delta

\section{Recommendations}

1. Courts should avoid technical rules of interpretation and exercise judicial liberality in interpreting right to life to make sure that the meaning of the right in judicial construction includes right to clean and healthful environment, means of livelihood as well as necessaries of food, shelter and clothing. 
2. It is our suggestion that a thorough environmental impact assessment should first and foremost be undertaken in compliance with Environmental Impact Assessment Act, 1992 before projects in oil and gas which have potentials for huge environmental pollution that desecrates right to life are executed in the Niger Delta.

3. Reasonable and sufficient compensation should be awarded by the Courts promptly to victims of environmental pollution whose lives are harmed. Government and Oil Companies ordered by Courts to pay damages to victims of pollution should obey Courts' orders as a matter of urgency. It is a high time that Courts stopped awarding of peanuts as damages in oil pollution cases

4. Rules of locus standi should be liberalized to allow a wider access to justice through representative, group or Community action.

5. Medical infrastructure should be established for victims of devastated environmental pollution related diseases.

6. The Ministry of Environment of Nigeria, National Environmental Standards and Regulations Agency and Oil Companies should work as team with other relevant Environmental Agencies to monitor oil spillages for prompt clean up exercises aiming at remediation and restoration of the environment.

\section{References}

Ajao and Anurigwo: www.greendiary.com/.../niger_delta-on-fire-demands-solution.

Akanbi, L. Judgment in Odi Case (http://www.vanguard.ngr.com/2013/odi-invasion-court-orders-fg-t...) Accessed on 15th September, 2014

Anaize, E., "Ugbokodo Accuses Shell of Pollution," Vanguard Newspaper, (Lagos) 2nd July, 2005.

Abdul Rasaq \& 3 others v. Inspector General of Police \& 5 Others, consolidated suit Nos. 10/499/91 and ID/333/94

Aliu Bello v. A.G. of Oyo State (1996) 5 NWLR Pt 45 P.828 at $887-889$

Akpamgbo, C., ed. (1992)Perspectives on Human Rights, Lagos: Federal Ministry of Justice of Nigeria.

A.G. of the Gambia v. Jobe (1984) AC 689 at 700

Alaibe, http://allafrica.com/stories/2008102306 $96 \mathrm{html}$.

Adediran and Another v. Inter-land Transport Limited (1992) NWLR Pt 214, P. 155

Black, H.C., etal, (1990)Black's Law Dictionary, 6 th ed., (St. Paul, Minn. U.S.A: West Group. (Babatunde citing Constitutional Rights Project: http://www.review.upeace. org/index.cfm?opcion=0\&ejemplar=20...).

Babatunde citing UNDP Report, 2006) http://www.review.upeace.org/index.cfm?opcion =0\&ejemplar=20....

Civil Liberties Organization, (1996) Justice for Sale: A Report of the Administration of Justice in the Magistrates and Customary Courts of Southern Nigeria, Lagos: Toma Publishers.

Civil Liberties Organization, (2002)Blood Trail: Repression and Resistance in the Niger Delta Lagos: CLO

Chambers v. Florida 309 US 22 at 241 (1940)

Ebegbulem, S., "Oil Spill Causes Damage in Uvwie", Vanguard Newspaper, (Lagos) 23rd July, 2009

Eze, O. (1984) Human Rights in Africa: Some Selected Problems, Nigeria:Macmillan,

Environmental Impact Assessment Act, 1992

Earth Rights Institute, http://www.earthrights.net/nigeria/news/defination, html

Francis Coralie v. Union Territory of Delhi AIR 1981 Sup.ct. 746 (App.5)

Fundamental Rights (Enforcement Procedure) Rules, 2009http://www.hedon unto/methanol stoves for indoor air pollution in Delta State, Nigeria.

Harmful Waste ( Special Criminal Provisions) Act, 2004).

Ihemagbulem, I., "Delta Slams Shell on Oil Spillage," Daily Sun (Lagos) 28th July, 2005.

Indian Council for Enviro-Legal Action v. Union of India (1996) 3 SCC 212, India.

Mohini Jain v. State of Karnataka, AIR 1992 Sup. Ct 1864 (App.6)

Mobil Producing Nigeria Unlimited v. Monokpo (2001) 18 NWLR Pt 744, P. 212

Nigerian Constitution, (1999) as amended

National Environmental Standards and Regulatory Agency Act, 2004

Obasogie, S. (2008) "Degreasing Environmental and climatic problems of Niger Delta and Associated Health Problems: A synopsis." http://www.globalforum health.org/filesupld/ young\%20voices/08/art/young voices.

Okorodudu -Fubura, M.T. (1998)., Law of Environmental Protection, (Ibadan: Caltop Publication Nig. Ltd.

Ordinioha and Brisibe, http://www.ncbi.nlm.nih.gov/ pmc/articles/pmc36447381

Pollution (http://en.wikipedia.org/wiki/Envi...)

Ramalingam, S.T. (1990), Modern Biology for Secondary School, 3rd ed. (Onistsha: African First Publishers Ltd.

Rabiu v. State (1981) 2 NCLR P. 293 at 326

Siegel, F.R, (1974) Applied Geochemistry, (New York: John \& Son Inc.

Seismograph Service (Nig.) Ltd v. Ogbeni (1976) 4 SC 83

Shell Petroleum Development Company of Nig. Ltd v. Chief Otoko and others (1990) 6 NWLR Pt 159,P.693 
Shikyl, S., "Judicial Attitude to Human Rights in Nigeria under Civilism Dispensation" (1997)3 UNIJOS Law Students Journal.Wikipedia, The Free Encyclopedia. 